\title{
Participatory Improved Beekeeping Technology Demonstration and Evaluation, Daro Labu, Western Hararghe, Oromia Regional state, Ethiopia
}

\author{
*Sudi Dawud ${ }^{1} \quad$ Kasahun Lemi ${ }^{2}$ \\ 1. Oromia Agricultural Research Institute, Mechara Agricultural Research Center, PO box 19
}

\begin{abstract}
Participatory demonstration and evaluations of improved beekeeping technologies were conducted in Daro labu district of West Hararghe zone with major objectives of demonstrating improved beekeeping technologies \& strengthen research-extension-farmers linkage in beekeeping technology generation and transfer. Demonstration and evaluations of box \& transitional hive with ant protection, bee management and product processing was conducted by forming farmers research groups(FRGs) at 4 peasant association (PAs) of Daro labu district; from the demonstration an average of $25.16 \mathrm{~kg}$ semi-extracted, $12.6 \mathrm{~kg}$ and $6 \mathrm{~kg}$ crude honey per hive/annum was harvested using box, transitional and traditional hives with ant protection respectively and bees wax purification was also demonstrated on farmers field. Therefore, all the demonstrated and evaluated technologies have been recommended for the mandate area to further promote the technologies in to the areas where there is a gap in utilizing and disseminating the technologies.
\end{abstract}

DOI: $10.7176 / \mathrm{JNSR} / 9-5-08$

Publication date:March $31^{\text {st }} 2019$

\section{Introduction}

In Ethiopia, beekeeping has been practiced for centuries and its potential is well documented. Of all the countries in the world, no country has such a long tradition of beekeeping than Ethiopia (Nebiyu Y and Messele T, 2000). Despite its long history, beekeeping in Ethiopia is still an undeveloped sector of agriculture. The knowledge and skill of honey and beeswax production of Ethiopian farmers is still very traditional (MoARD,2003). Most of local beehives are hanged over high trees. Honey production from honeybees are very low with an average of 5-6 kg per hive per year, while from the improved one average of $15-20 \mathrm{~kg}$ even more is possible. Honey and beeswax are collected after rainy season; starting from October to December. In the South and Eastern parts, in addition to the main, there is minor harvesting period during May-June. According to CSA, the major honey and beeswax producing regions in Ethiopia are Oromia (41\%), SNNPR (22\%), Amhara (21\%) and Tigray (5\%) (CSA, 2003). However, the country is suffering from the ecological degradation of its natural resources and this means the basis for any honey production is threatened and affected. In many regions of the country, beekeeping is considered as one of the incomegenerating activities for resource-poor farmers including women, youth and the unemployed sectors of the community (Gezahegn T, 2001).

About $10 \%$ of the honey produced in the country is consumed by beekeeping households. The remaining $90 \%$ is sold for income generation; of this amount, it is estimated that $70 \%$ is used for brewing 'tej' (local alcoholic beverage) and the balance is consumed as table honey. Additionally beeswax is collected and traded. Honey is a vital factor in job creation and maintaining livelihoods. However, current honey production estimate represents only 8.6\% of the country's production potential (Nebiyu Y and Messele T, 2000, MoARD, 2003, Paulos D 2011, ARSD, 2000). Beekeeping is still operating in the old traditional ways implying the need for modernization. Low productivity and poor quality of bee products are the major economic impediments for rural beekeepers (Nuru A 1999); however, they face another primary economic concern; i.e. lack of skill to manage their bees and bee products.

The country, Ethiopia is naturally endowed with melifrous plant spp., diversified climate and agro-ecologies which favor the presence of millions of honey bee colonies. However, the productivity of beekeeping sub-sector is very low as compared to potentials the country posses. Low production and productivities of beekeeping subsector is attributed to lack of improved beekeeping technologies and low skills of beekeepers. The types of hive used, methods of extraction and honey storage means play a vital role for determination of quality honey. Lack of improved beekeeping technologies (different beekeeping equipments for production, processing \& storages of hive product, poor colony managements and miss handling from the time of its harvest until it reaches end users) are the main factors to produce less quantity and inferior quality honey. It is vital to note that no amount of research will lead to sustainable agricultural development if the countries in Africa do not address the constraints to sustainable agriculture (Chambers et al, 1989).

Most importantly, they have to use an extension strategy that allows the stakeholders to be part of the research agenda. When the stakeholders to agricultural research are part of the planning and implementation, they have the sense of belonging and ownership. The use of Farmers Research Group (FRG) is one of the approaches, which 
integrates indigenous knowledge's of the farmers and scientific research which leads to develop client- oriented research that can tackle the problems of the beneficiaries.

The study was conducted with the main objectives of demonstrating beekeeping technologies through participatory approach and strengthening research-extension-farmer linkage in beekeeping technology generation and transfer.

\section{Materials and Methods}

The study was carried out in four PAs of Daro Labu district through participatory approaches. In each PAs, one FRG containing 15 members in to three demonstration sites (apiary of voluntary beekeepers), in which case a total of 4 FRGs were established containing 12 demonstration sites. Demonstration was carried out on Box, Chefeka and traditional hives (as a control) with ant protection and bee management (colony transfer, dearth period colony management, swarm control, hive inspection, and replacement of old and damaged combs) and purifications of crude bees wax in to pure beeswax.

\section{Training}

Following the establishments of FRGs, first phase training was given on the advantages, disadvantages, types of beekeeping and practical transitional hive constructions at each respective site for two days in which the farmer can construct transitional hive and hive stand from locally available materials and colony transfer was made with the farmers following transitional hive construction and delivering of box hive with other required in puts.

Figure 1: Farmers constructing transitional hives from locally available materials

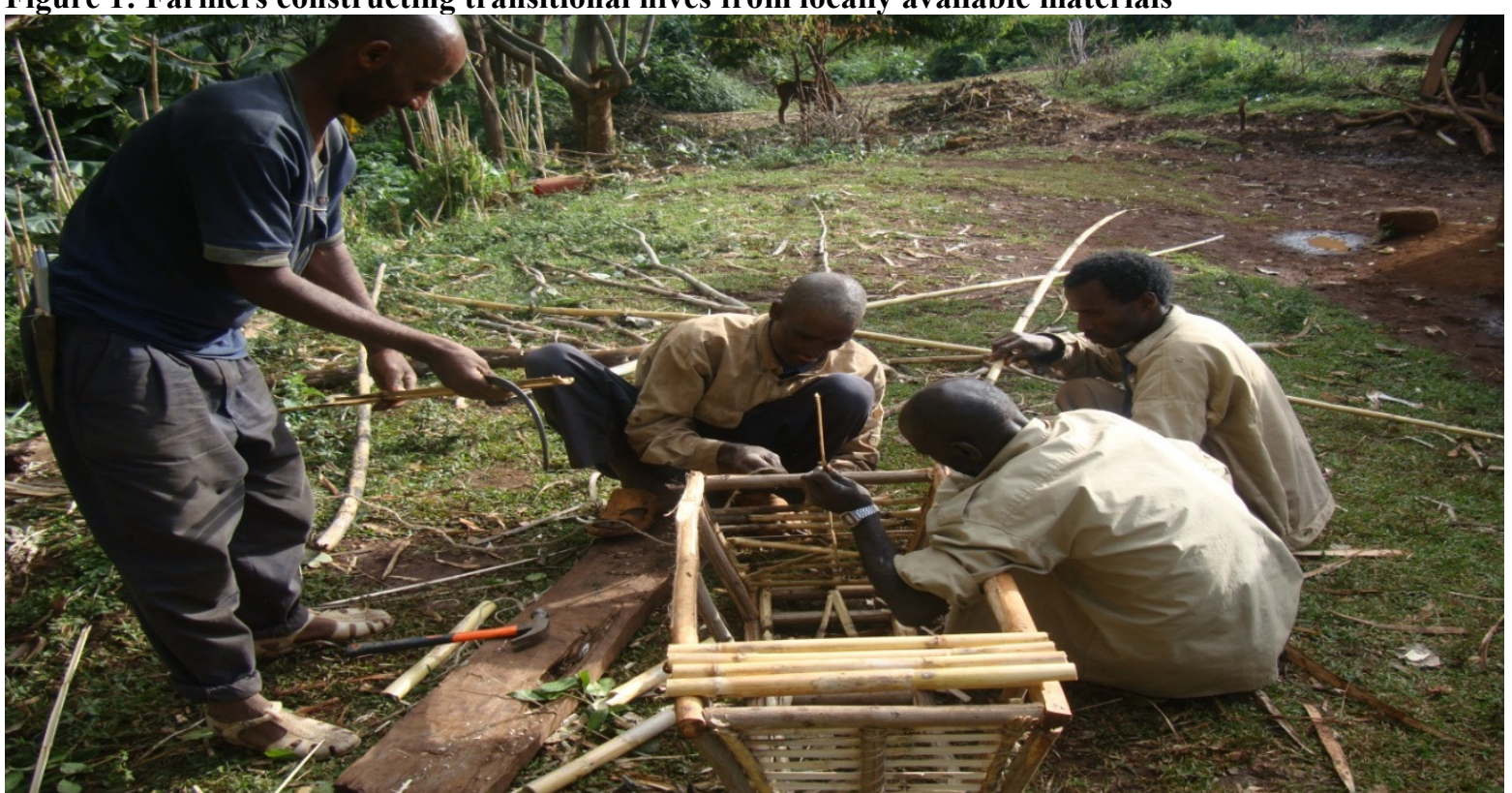

Second phase training was also organized and given to 12 experimental farmers, 4 development agent (DAs) and 1 beekeeping expertise at the end of $1^{\text {st }}$ year of experiment on improved beekeeping (colony transferring, dearth period colony management, hive inspection, honey harvesting and wax purification ) at Mechara agricultural research center.

The final phase of the training was also given to experimental farmers, DAs and expertise on the $3^{\text {rd }}$ year of the experiment or termination of the project with the main objectives of strengthening research-extension- farmer's linkage on beekeeping technology generation and promotion and assesses farmer's feedback.

\section{Data collection and analysis}

During the study, data were collected on hive acceptance by honey bees, honey yield from different hives (box, transitional and traditional hives), attitudes of the farmers towards improved beekeeping technologies were gathered and analyzed using descriptive statics.

\section{Results and Discussion}

Demonstration and evaluations of box \& transitional hive with ant protection, bee management and product processing was conducted by forming 4 FRGs at 4 PAs of Daro Labu and from the demonstration an average of $\mathbf{2 5 . 1 6} \mathrm{kg}$ semi-extracted honey, $\mathbf{1 2 . 6}$ and $\mathbf{6} \mathrm{kg}$ crude honey per hive/annum was harvested using box, transitional and traditional hives with ant protection respectively. On the other hand, 3 FDG (demonstration sites) was dropped (data were not collected) due to burning of one demonstration colony at Sakinna FRG by unknown reason and inaccessibilities of the site to road (Café Hara and Mata Gudessa FRGs). 
Table 1: acceptance of box and transitional hives by honey bees at different demonstration sites

\begin{tabular}{|c|c|c|c|c|c|}
\hline$\stackrel{\dddot{\Xi}}{\stackrel{N}{N}}$ & : & $\begin{array}{l}\text { Peasant } \\
\text { association (PA) }\end{array}$ & Demonstration site & $\begin{array}{l}\text { No of bee colonies } \\
\text { transferred to box } \\
\text { \& transitional hive }\end{array}$ & $\begin{array}{l}\text { No of bee colonies } \\
\text { accepted to box \& } \\
\text { transitional hive }\end{array}$ \\
\hline \multirow{13}{*}{ 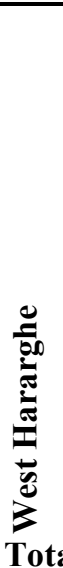 } & & \multirow[t]{3}{*}{ Café hara } & Group one & 2 & 2 \\
\hline & & & Group two & 2 & 0 \\
\hline & & & Group three & 2 & 2 \\
\hline & & \multirow[t]{3}{*}{ Mata gudessa } & Micheta & 2 & 2 \\
\hline & & & Mata Guddeessa & 2 & 1 \\
\hline & & & Cirati & 1 & 1 \\
\hline & & \multirow[t]{3}{*}{ Oda laku } & Ganda odaa & 2 & 2 \\
\hline & & & Ganda alaa & 2 & 2 \\
\hline & & & Group three & 2 & 2 \\
\hline & 气 & \multirow[t]{3}{*}{ Sakinna } & Sakina & 2 & 2 \\
\hline & $\stackrel{0}{2}$ & & Gido & 2 & 2 \\
\hline & อี & & Huluqo & 1 & 1 \\
\hline & \multicolumn{3}{|c|}{ umbers of bee colony } & 22 & 19 \\
\hline
\end{tabular}

Table 2: annual honey yield comparison of box, transitional and traditional hives

\begin{tabular}{|c|c|c|c|c|c|c|}
\hline \multirow{2}{*}{$\stackrel{\ddot{\Xi}}{\stackrel{0}{N}}$} & \multirow{2}{*}{ 苞 } & \multirow[t]{2}{*}{ PA or FRG } & \multirow[t]{2}{*}{$\begin{array}{l}\text { Demonstration } \\
\text { site }\end{array}$} & Box hive & $\begin{array}{l}\text { Transitional } \\
\text { hive } \\
\end{array}$ & $\begin{array}{l}\text { Traditional } \\
\text { hive } \\
\end{array}$ \\
\hline & & & & $\mathrm{Kg}$ /hive/annum & Kg/hive/annum & $\mathrm{Kg}$ /hive/annum \\
\hline \multirow{8}{*}{ 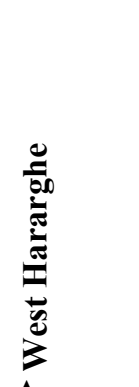 } & \multirow{8}{*}{ 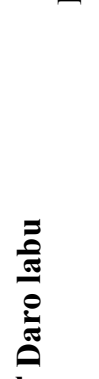 } & \multirow[t]{2}{*}{ Café hara } & Group one & 19 & 0 & 7 \\
\hline & & & Group three & 0 & 12 & 6 \\
\hline & & Mata gudessa & Micheta & 38 & 0 & 6 \\
\hline & & \multirow{2}{*}{ Oda laku } & Ganda oda & 30 & 14 & 4 \\
\hline & & & Ganda ala & 18 & 10 & 6 \\
\hline & & \multirow{3}{*}{ Sakinna } & Group three & 0 & 9 & 5 \\
\hline & & & Gido & 29 & 18 & 8 \\
\hline & & & Huluqo & 17 & 0 & 6 \\
\hline $\begin{array}{l}\text { Average } \\
\text { honey) }\end{array}$ & honey & yield obtained & (crude & 25.16 & 12.6 & 6 \\
\hline
\end{tabular}

*FRG $=$ farmer research group, $* \mathrm{PA}=$ Peasant association

Table 3: price of crude honey at each respective demonstration sites

\begin{tabular}{|c|c|c|c|c|}
\hline No. & FRGs (peasant association) & Unit & Average unit price & Remark \\
\hline 1 & Café hara & $\mathrm{Kg}$ & 170.00 & With comb \\
\hline 2 & Mata gudessa & “ & 182.00 & Semi-extracted \\
\hline 3 & Oda laku & “ & 150.00 & “ \\
\hline 4 & Sakinna & ، & 180.00 & ، \\
\hline & Average price in the dis & & 170.5 birr & \\
\hline
\end{tabular}

Field day and visit

On the second year of the experiment field day and visit was arranged at one FDG (Micheta site) apiary of one beekeeping farmers with the main objectives of observing apiary site management, effectiveness of different technologies and demonstrating crude bees wax purification methods to farmers. The participants were experimental farmers, DAs and expertise. 


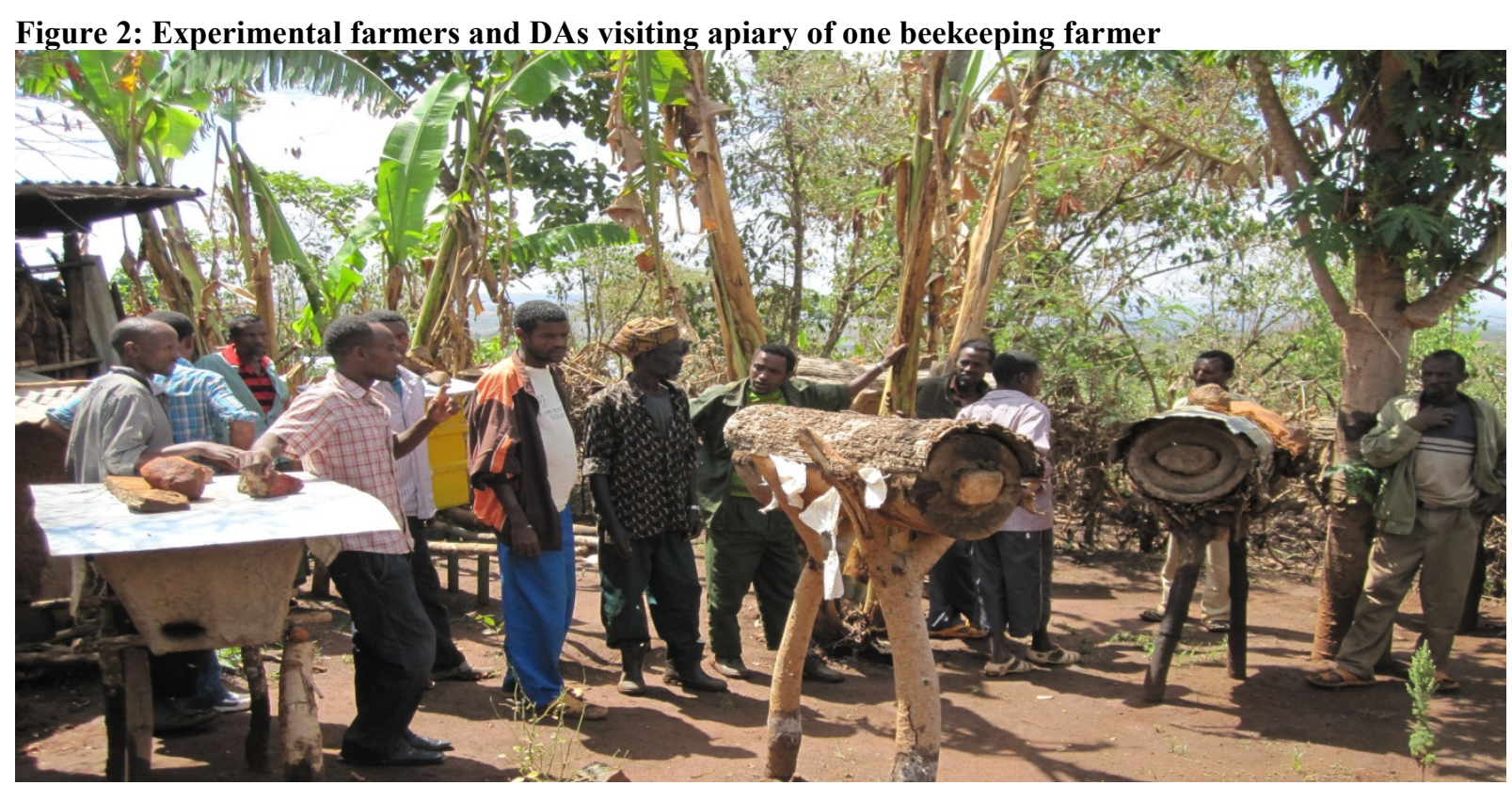

Figure 3: Experimental farmers and DAs demonstrating wax purification on farmer's field

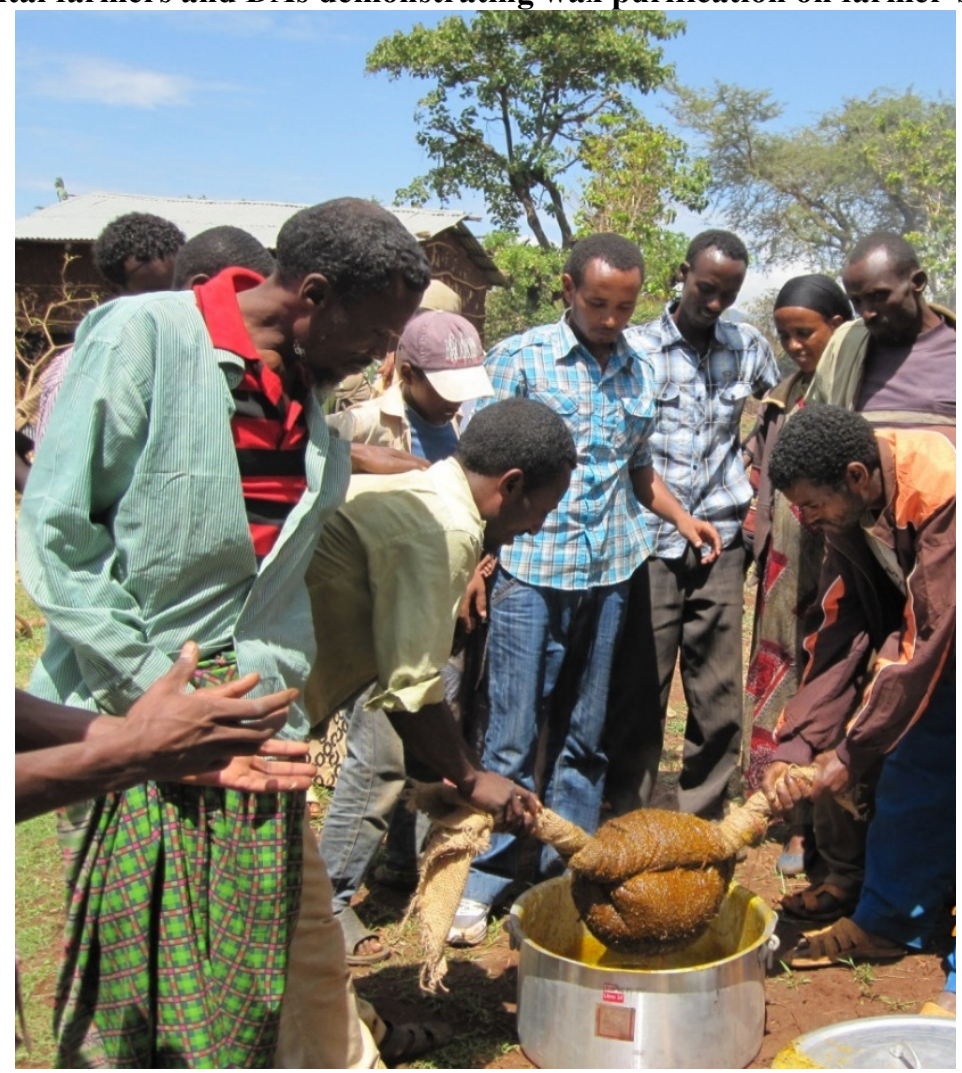

\section{Conclusions and Recommendations}

Demonstration and evaluation of improved beekeeping technologies through participatory approach is one means of technology promotion to large numbers of technologies beneficiaries in areas where there is a need to popularize the technologies. Accordingly, from the evaluation made improved beekeeping technologies and other accessory equipments with it is improved management practice intervention found to boost production and productivity of beekeeping sub-sectors in the demonstrated areas. Therefore, the technologies is feasible and strongly recommended to be popularized for maximizing honey production and alleviating the existing problems on shortages of improved beekeeping technologies and poor management practice. From this, for effective utilization of the technologies, short-term beekeeping training to beekeeping farmers, DAs and expertise is required. Further 
promotions of the technologies in to the area where there is a gap in utilizing the technology is must by governmental and non-governmental organizations including Mechara agricultural research center.

\section{REFERENCE}

ARSD (Apiculture Research Strategy Document) (2000) Apiculture research strategy document. EARO (Ethiopian Agricultural Research Organization), Addis Ababa, Ethiopia.

Chambers R, P.Arnold, T.Lorri Ann (Eds). 1989. Farmer first: Farmer innovation and agricultural research. London, Intermediate technology publications.

CSA (Central Statistical Authority) (2003) Statistical report on livestock and livestock products. CSA, Addis Ababa, Ethiopia. Official document.

Gezahegn T (2001) Apiculture development strategies. MoARD (Ministry of Agriculture and Rural Development), Addis Ababa, Ethiopia.

MoARD (Ministry of Agriculture and Rural Development) (2003) Honey and beeswax production and marketing plan. Amharic version. MoARD, Addis Ababa, Ethiopia.

Nebiyu Y, Messele T (2000) Honeybee production in the three Agroecological districts of Gamo Gofa zone of southern Ethiopia with emphasis on constraints and opportunities. Agric Biol J N Am 4: 560-567.

Nuru A (1999) Quality state of grading Ethiopian honey. In: Proceedings of the first national conference of the Ethiopian Beekeepers Association, Addis Ababa, Ethiopia.

Paulos D (2011) Ethiopian Honey: Accessing International Markets with Inclusive Business and Sector Development.

Workneh A, et al, 2007, participatory beekeeping technology promotion: A case of chefeka hives pp.74, Proceedings of fifth national annual conference of the Ethiopian beekeepers association, August 2007, Addis Ababa. 